\title{
Telekonsultasi Dalam Rangka Pemutusan Rantai Penularan Covid-19 di Kota Bengkulu
}

\section{Dessy Triana*1, Hardiansyah $^{2}$, Sri Yunita ${ }^{3}$, Miftahul Haniyah ${ }^{4}$, Enny Nugraheni Sulistiyorini $^{5}$, Riry Ambarsarie ${ }^{6}$, Rizkianti Anggraini ${ }^{7}$, Elvira Yunita ${ }^{8}$, Mardhatillah Sariyanti'}

${ }^{13456789}$ Fakultas Kedokteran dan Ilmu Kesehatan, Universitas Bengkulu

${ }^{2}$ Fakultas Teknik, Universitas Bengkulu

E-mail*: dessy.triana@unib.ac.id

\section{Article History}

Received: Oktober

2021

Revised: Oktober 2021

Accepted: November

2021

Available online:

Desember 2021

Keywords:

Covid-19, Social

distancing,

Teleconsultation,
Abstract: Coronavirus Disease-19 (Covid-19) is a disease that has become a global epidemic. The World Health Organization (WHO) has declared Covid-19 a pandemic. Indonesia declared the status of the Covid-19 disease to be an Emergency Response. Supporting the social distancing, the right strategy is needed to continue implementing health services amid the Covid-19 pandemic. This activity aimed to provide knowledge related to Covid-19 to the community and health consultations and medical advice through applications (teleconsultation) to minimize patients queuing at Health Service Facilities directly. The activity partners were the Indonesian Medical Association (IDI) Bengkulu City Branch, Bengkulu City Health Office, and the Indonesian Red Crescent (BSMI) Bengkulu City Region. The method of this activity was to provide socialization, health consultation and medical advice through applications (teleconsultation) regarding the spread, transmission and prevention of Covid-19 from May 1 to August 31 2020. The number of participants was 41 people from Bengkulu City. The highest number of diseases consulted were acute respiratory infections (38.7\%.) and Covid- 
19 independent protocol consultation $(31.58 \%$.) Teleconsultation can be continued and developed into a patentable application. Application development is indispensable in responding to the challenges of the health world in the digital era.

\section{Pendahuluan}

Coronavirus Disease-19 (Covid-19) merupakan wabah secara global atau pandemi (George, 2020). Penyakit ini pertama kali dilaporkan dari Wuhan, Provinsi Hubei, Tiongkok dengan keluhan pneumonia dengan penyebab yang tidak diketahui (WHO, 2020a). Pemeriksaan pasien di Wuhan menunjukkan infeksi coronavirus jenis betacoronavirus tipe baru dan diberi nama Novel Coronavirus (2019-nCoV) (Huang et al., 2020). Pada tanggal 11 Februari 2020, World Health Organization (WHO) memberi nama virus baru tersebut Severe Acute Respiratory Syndrome Coronavirus-2 (SARS-CoV-2) dan nama penyakitnya sebagai Coronavirus Disease 2019 (Covid-19) (WHO, 2020b). Coronavirus (CoV) adalah virus RNA strain tunggal positif, berkapsul dan tidak bersegmen. Coronavirus bersifat zoonotik yaitu penularan dari hewan ke manusia. Terdapat 4 genus yaitu $\alpha$-coronavirus, $\beta$-coronavirus, $\delta$ coronavirus dan $\gamma$ - coronavirus (Huang et al., 2020; Qiang and Ke, 2020)

Rekomendasi standar untuk mencegah penyebaran infeksi diantaranya mencuci tangan secara teratur, menutup mulut dan hidung ketika batuk dan bersin, memasak daging dan telur dengan matang. Pencegahan penyebaran Covid-19 akibat droplet yang menempel pada permukaan benda dapat dilakukan dengan desinfeksi lingkungan (Kementerian Kesehatan RI, 2020a).

Usaha promosi kesehatan harus tetap dilakukan sebagai upaya pencegahan terhadap Covid-19 yang sedang mewabah. Promosi kesehatan biasanya dilakukan secara tatap muka, akan tetapi akan memperluas penyebaran Covid-19. Sehingga salah satu cara untuk meningkatkan pengetahuan mengenai penularan penyakit Covid-19 melalui aplikasi dapat menjadi solusi pada kondisi pandemi. Sosialisasi dan konsultasi antara pasien 
dan dokter tidak dilakukan secara tatap muka dan tujuan akhir dapat meningkatkan kualitas hidup dan kesehatan masyarakat dalam memutus rantai penularan Covid-19 dapat tercapai (Kementerian Kesehatan RI, 2020b).

Penyebaran penyakit yang begitu cepat, sehingga diperlukan strategi dan solusi yang tepat dan efektif untuk tetap melakukan pelayanan kesehatan tetapi tidak melakukan kontak fisik atau tatap muka dalam rangka pencegahan perluasan penyebaran penyakit Covid-19. Telemedicine merupakan salah satu pengembangan sektor kesehatan pada bidang digital. Aktivitas ini dikenal dengan nama "healing at a distance" dan telah dilakukan sejak tahun 1970. Telemedicine merupakan sebuah sistem untuk melakukan terapi medis dan tidak terhalang ruang (WHO, 2010; Kuntardjo, 2020).

Telekonsultasi adalah salah satu bagian dari telemedicine. Telekonsultasi merupakan suatu teknologi yang memberikan fasilitas berupa kemudahan pasien untuk berdiskusi dengan dokter tanpa melakukan pertemuan secara langsung. Harapan hasil diskusi dapat membantu pasien dalam menerima informasi mengenai dugaan diagnosis, perawatan atau penanganan pertama pada penyakit, informasi dalam meningkatkan kesehatan dan kebugaran tubuh serta kesehatan mental masyarakat pada masa pandemi Covid-19 ini. Oleh karena itu, tujuan dari pengabdian masyarakat ini adalah menginformasikan telekonsultasi dalam melakukan pelayanan kesehatan di masa Pandemi Covid-19, sehingga meningkatkan kualitas hidup dan kesehatan masyarakat secara luas dalam rangka pencegahan peningkatan dan perluasan kasus Covid-19 di Kota Bengkulu.

\section{Metode}

Metode kegiatan pengabdian ini memberikan sosialisasi, konsultasi kesehatan dan pengobatan berbasis teknologi melalui aplikasi yaitu Aplikasi Tawk, Whatsapp dan SMS tentang penyebaran dan penularan penyakit Covid19 serta pencegahannya dan memberikan anjuran medis dan pengobatan kepada masyarakat yang memiliki keluhan kesehatan yang tidak termasuk kriteria gawat darurat. Kegiatan ini dilaksanakan dengan kerjasama antara Fakultas Kedokteran Universitas Bengkulu dengan Ikatan Dokter Indonesia 
(IDI) Cabang Kota Bengkulu dan Relawan Bulan Sabit Merah Indonesia (BSMI) Perwakilan Bengkulu. Kegiatan dilaksanakan sejak tanggal $01 \mathrm{Mei}$ 2020 sampai 31 Agustus 2020 dan terdapat 41 orang yang terdaftar dalam telekonsultasi.

\section{Hasil}

Kegiatan telekonsultasi telah dilaksanakan dari tanggal 01 Mei 2020 sampai dengan 31 Agustus 2020 melalui aplikasi Tawk, Whatsapp, SMS. Hasil konsultasi kesehatan online menggunakan Aplikasi Tawk sebanyak 16 orang. Hasil telekonsultasi menggunakan aplikasi Whatsapp sebanyak 22 orang dan melalui aplikasi SMS sebanyak 3 pasien, semua pasien berasal dari kota Bengkulu. Layanan melalui aplikasi dengan melakukan penapisan awal untuk Covid-19 dan dilanjutkan percakapandalam rangka memperdalam anamnesis untuk penegakan diagnosis d. Persentase jenis keluhan atau penyakit dapat dilihat pada Gambar 1.

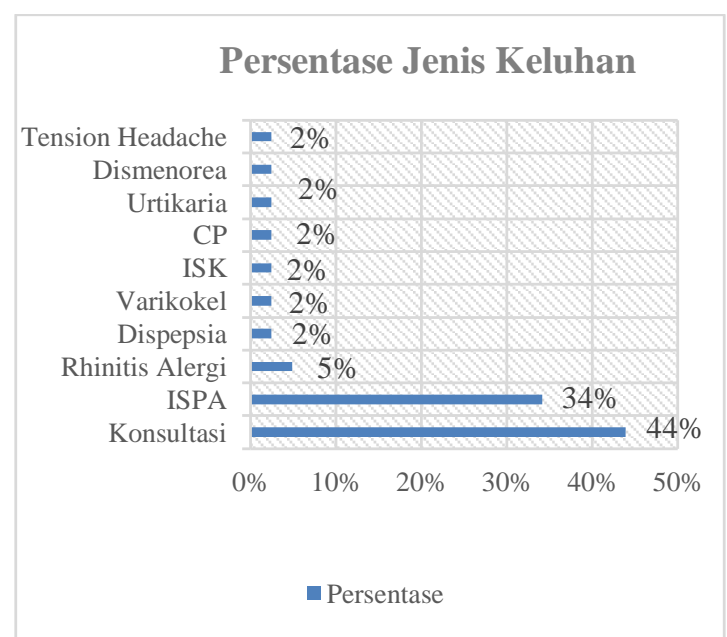

Gambar 1. Persentase Jenis Keluhan Pasien

Hasil dari telekonsultasi penyakit atau topik terbanyak yang diderita adalah konsultasi kesehatan dan Covid-19 sebanyak 44\% diikuti penyakit saluran nafas akut sebanyak 34\%. Telekonsultasi merupakan bagian dari telemedicine sehingga cakupannya lebih sempit. Melakukan penerapan 
konsultasi online di lapangan ini membantu pasien berkonsultasi langsung dengan dokter mengenai kesehatannya tanpa harus kontak fisik atau tatap muka. Cakupan konsultasi online antara lain: komunikasi perihal keluhan dari pasien kepada dokter, pemberian diagnosis dari dokter kepada pasien dan pemberian saran tata laksana dari dokter kepada pasien, seperti pengobatan dan tindakan medis (WHO, 2010; Lee et al., 2015).

Peraturan Menteri Kesehatan nomor 20 tahun 2019 belum mengatur secara detail dan menyeluruh mengenai konsultasi online melalui aplikasi, tetapi setiap penyedia layanan konsultasi kesehatan harus memiliki prosedur dan syarat yang harus dipenuhi saat melakukan aktivitas ini (Kementerian Kesehatan, 2019). Telekonsultasi adalah perkembangan teknologi untuk membantu menyelesaikan masalah kesehatan yang memiliki kendala akses terbatas ke fasilitas kesehatan. Layanan ini diatur oleh Kementerian Kesehatan melalui kerja sama dengan penyedia jasa konsultasi secara daring dengan dokter melalui situs website atau aplikasi di smartphone (Ariyanti and Kautsarina, 2017; Kementerian Kesehatan, 2019).

\section{Pembahasan}

Telemedicine merupakan pemanfaatan perkembangan teknologi informasi dan komunikasi untuk memberikan layanan medis dari jarak jauh. Program ini adalah salah satu strategi untuk mengatasi permasalahan akses fasilitas kesehatan di Indonesia. Fasilitas aktivitas dapat dilakukan melalui telepon, panggilan video, situs internet atau alat komunikasi canggih lainnya (Lee et al., 2015). Dalam pelaksanaannya meliputi 2 konsep yaitu real-time (synchronous) dan store-and-forward (asynchronous). Konsep synchronous memerlukan kehadiran kedua belah pihak pada saat aktivitas berlangsung, karena diperlukan interaksi antara kedua belah pihak, sedangkan konsep asynchronous tidak memerlukan kehadiran kedua pihak karena evaluasi data medis dilakukan secara offline (Kuntardjo, 2020).

Telemedicine di Indonesia berdasarkan panduan IDI ada 5 konsep, yaitu: tele-expertise (menghubungkan dokter umum - dokter spesialis atau antar dokter spesialis), tele-consultation (menghubungkan pasien - dokter), 
tele-monitoring (digunakan untuk monitor kondisi tubuh pasien), teleassistance (untuk memberikan arahan kepada pasien) dan tele-robotic (pengendalian jarak jauh melalui robot dalam suatu tele-surgery) (IDI, 2018).

Dalam beberapa studi terdahulu, beberapa negara telah menerapkan program telekonsultasi dengan berbagai nama dan variasi jenis pelayanan. Kegiatan ini dapat menurunkan angka kematian terutama pada daerah-daerah dengan akses kesehatan yang tidak memadai (Ariyanti and Kautsarina, 2017). Telekonsultasi digunakan dalam penanganan kasus yang tidak gawat darurat dan penyakit kronis yang terkontrol (Ullah et al., 2021).

Kelebihan lain dari telekonsultasi ini adalah praktis dan layanan konsultasi bersifat gratis, dengan beberapa ketentuan bahwa daerah tersebut memiliki listrik dan koneksi internet yang memadai, minimal teknologi 3G (Wiweko, Zakirah and Luthfi, 2021). Manfaat lainnya adalah untuk mengatasi cyberchondria atau kekhawatiran berlebih yang timbul pada seseorang setelah membaca informasi di internet tentang suatu penyakit dengan gejala yang sama dengan yang dirasakan dan melakukan diagnosis sendiri berdasarkan sumber informasi yang tidak pada sumber yang sesuai (Kementerian Kesehatan, 2019).

Telekonsultasi dapat dikembangkan di Indonesia dengan anggaran yang tidak terlalu besar (sekitar 19\% dari anggaran Kementerian Kesehatan pada Tahun 2015) (Ariyanti and Kautsarina, 2017). Peningkatan akses internet yang baik akan menunjang pelayanan kesehatan yang baik dan memiliki dampak peningkatan kualitas kesehatan masyarakat Indonesia terutama pada daerah tertinggal dan terluar/perbatasan sehingga angka kesakitan dan kematian dapat dikendalikan.

Telekonsultasi ini juga dapat membantu program Jaminan Kesehatan Nasional (JKN) yang telah diselenggarakan sejak tahun 2014 dan memiliki strategi untuk melakukan universal coverage atau memastikan bahwa seluruh masyarakat Indonesia dapat mengakses pelayanan kesehatan tanpa terkecuali (UU RI, 2014). Telekonsultasi menjadi awal untuk perkembangan teknologi informasi dan komunikasi di sector Kesehatan. 


\section{Kesimpulan}

Jumlah peserta yang mengikuti kegiatan telekonsultasi sebanyak 41 orang dan berasal dari Kota Bengkulu. Jumlah penyakit terbanyak yang dikonsultasikan adalah konsultasi protokol mandiri Covid-19 (44\%) dan infeksi saluran pernafasan akut (34\%.). Telekonsultasi melalui aplikasi Tawk mempunyai potensi untuk dikembangkan menjadi aplikasi yang dapat dipatenkan. Pengembangan aplikasi sangat diperlukan dalam menjawab tantangan dunia kesehatan pada era digital.

\section{Daftar Referensi}

Ariyanti, S. and Kautsarina, K. (2017) 'Kajian Tekno-Ekonomi pada Telehealth di Indonesia', Buletin Pos dan Telekomunikasi, 15(1), p. 43. doi: 10.17933/bpostel.2017.150104.

George, Y. W. H. (2020) Panduan Tatalaksana Pasien Diduga Infeksi COVID19 dengan ARDS dan Syok Sepsis Berbasis Bukti.

Huang, C. et al. (2020) 'Clinical features of patients infected with 2019 novel coronavirus in Wuhan, China', The Lancet, 395(10223), pp. 497-506. doi: 10.1016/S0140-6736(20)30183-5.

IDI (2018) 'Telemedicine Rekomendasi IDI untuk Masa Depan Digitalisasi Kesehatan di Indonesia', pp. 8-10.

Kementerian Kesehatan RI (2020a) 'Panduan Kegiatan Menjaga Kebersihan Lingkungan dan Langkah-Langkah Desinfeksi dalam Rangka Pencegahan Penularan COVID-19', pp. 1-15.

Kementerian Kesehatan RI (2020b) 'Sistem Rujukan Covid-19 di Indonesia', pp.1-5.

Kementerian Kesehatan. (2019) 'Peraturan Menteri Kesehatan Republik Indonesia nomor 20 tahun 2019 tentang penyelenggaraan pelayanan', pp. $1-15$.

Kuntardjo, C. (2020) 'Dimensions of Ethics and Telemedicine in Indonesia: Enough of Permenkes Number 20 Year 2019 As a Frame of Telemedicine Practices in Indonesia?', Soepra, 6(1), pp. 1-14. doi: 10.24167/shk.v6i1.2606.

Lee, J. K. et al. (2015) 'Guest editorial: Telehealth Systems and Applications', Journal of Signal Processing Systems, 80(3), pp. 241-243. doi: 10.1007/s11265-015-0970-z. 
Qiang, W. and Ke, H. (2020) A Handbook of 2019-nCoV Pneumonia Control and Prevention.

Ullah, S. M. A. et al. (2021) 'Scalable Telehealth Services to Combat Novel Coronavirus (COVID-19) Pandemic', SN Computer Science, 2(18), pp. 1-8. doi: 10.1007/s42979-020-00401-x.

UU RI (2014) Undang-Undang Republik Indonesia Nomor 40 Tahun 2014 Tentang Perasuransian. Jakarta, pp. 1-86.

WHO (2010) 'Telemedicine: Opportunities and developments in Member States', Global Observatory for eHealth Series, 2, pp. 1-96.

WHO (2020a) 'Pencegahan dan Pengendalian Infeksi ( PPI ) Novel Coronavirus ( COVID-19 ) Prinsip-prinsip Manajemen Kedaruratan', pp. 1-45.

WHO (2020b) 'Severe Acute Respiratory Infections Treatment Centre D4', (January), pp. 1-50.

Wiweko, B., Zakirah, S. C. and Luthfi, A. (2021) 'The Essence of Telemedicine for Bridging the Gap in Health Services', Kesmas: National Public Health Journal, 16(2), pp. 66-70. doi: 10.21109/kesmas.v16i2.4896. 